\title{
REREADING PATRIARCHAL INTERPRETATIONS ON THE QUR'ĀN FROM HADITTH PERSPECTIVE IN THE EVE OF LAW NO. 23/2004 ON THE ELIMINATION OF DOMESTIC VIOLENCE
}

\author{
Siti Aisyah \\ UIN Alauddin, Makassar - Indonesia
}

\begin{abstract}
Religious views on gender and man-woman relation in Indonesia is significant in shaping how the people including the survivors of the domestic violence perceive it. These views seem to be more intact than state initiative regulations, such as Law No. 23/2004 on the Elimination of domestic Violence. This paper tries to explore several things related to the domestic violence in Makassar, Indoneisa. The first is the correlation between the perception of survivors about domestic violence with their gender awareness. The second is the way that the constructed gender views are also influenced by religious interpretations. The last is the variety of interpretations on verses in the Qur'an related to gender and domestic violence. Most importantly, the paper also analyses the Qur'anic text in relation to the understanding of domestic violence justification and offer a new reading of the Qur'an using Hadith perspective.
\end{abstract}

Keywords: Domestic violence, family violence, survivor, good wife, disobedience.

\section{Introduction}

"My husband often got angry and hit me if my children or I went out without his consent. One day he hit me using a piece of balo-balo (wood). He also kicked me after I asked him not to drink alcohol. Now, I have a permanently broken knee... I feel so angry. This hurts me, but I cannot do anything, and I am scared he may kill me. I just 
put up with it."1

This is a story of one survivor of the domestic violence in Makassar, Indonesia. Another example is a story by the 38 years old woman who has been a victim of domestic violence as her husband physically and emotionally abuses her almost every day. The abuse is taking many many forms namely by kicking and hitting her for even small 'mistakes' such as being absent from home for household needs. The husband also gets angry and abuses her if she complains his alcohol drinking habit. Ironically, because of the abuse, she has a permanent broken knee. She also suffers psychological impairment like feeling humiliated, angry, and fear from being killed. In addition, feelings of entrapment and powerlessness are obvious as she never respond to the violence. ${ }^{2}$

Domestic violence in Indonesia, at least in Makassar where this study was conducted, is evident. There are many factors contributing to the occurence of domestic violence. One main factor behind this is unequal gender relation. Unfortunately, this gap or unequality in gender relation, is not only socially and culturally structured, but also influenced by religious understandings that have reinforced a clear gender hierarchy in Indonesian society. In light of this, it is important to critically examine Islamic teachings with respect to gender relations including domestic violence, and to consider how scholars interpret those teachings. This is, again, due to the fact that there are considerable influence from the religious believs inluding the interpretations on verses related to gender relation with the way people perceive domestic violence.

To give illustration, one survivor of domestic violence internalizes that domestic violence is acceptable for wrongdoings such as "ignoring her husband's good requests". 3 These women's accounts reflect the interconnection between textual understandings of the Qur'an and women's beliefs which result from social and cultural constructions. In

\footnotetext{
1 Author's Interview with a survivor of domestic violence, S 03, in Makassar (March $\left.4^{\text {th }}, 2004\right)$ I will use codes ' $S$ ' followed by numbers to indicate survivors who experienced domestic violence and 'RS' (for Religious Scholars). The purpose of these codes (as anonymous for respondents) is for confidentiality as this research was related to 'private concerns and abused experiences'.

2 Author's Interview with a survivor of domestic violence, S 03, in Makassar (March $\left.4^{\text {th }}, 2004\right)$.

3 Author's interview with S 04 in Makassar (March 4th 2004$)$.
} 
sum, as a consequence, these women tend to accept men's violence against women.

This paper aims to analyse the Qur'anic text in relation to the understanding on domestic violence justification and offer a new reading on the Qur'an using Hadith perspective. Data was collected from interviews with several survivors of domestic violence in Makassar and some Muslim scholars. They are interviewed in order to make the baseline data on how they understand domestic violence dan relates to Islamic teachings.

\section{Domestic Violence in Indonesia: Social Facts and How it Happens}

Domestic violence in Indonesia is a serious problem eventhough it is not well recorded both in the police reports or the NGOs hotlines. This is not because the occurence is low. Rather, it shows the reluctance of the survivors to be open, exposed and moreover to report the incidence of domestic violence. In term of legal regulation, domestic violence has been considered a crime since 2004 with the enactment of Law No. 23 of 2004 on the Elimination of Domestic Violence. The law defines domestic violence as "any action of force or threat that is against the law by any members of a family which has a significant impact on a person's health and well-being, particularly that of women". "The definition of domestic violence used in this study encompasses the use of force, threats or restrictions placed on women by men as well as emotional, economic and sexual dimensions of abuse against women by husbands. So, domestic violence is not limited to physical violence.

Among the Makassar women, there are different perceptions in defining domestic violence and these perceptions are also found in other parts of Indonesia. Interestingly, women activists and religious scholars may differ in their definitions, depending on their observations and experience of working with abused women. Women activists and religious counselors agree that domestic violence takes many forms including physical, emotional and economic abuse experienced by any family member including men, women and children within a family unit. This may also include restrictions on woman's right to have personal freedom, such as time for relaxation.

${ }^{4}$ Law No. 23/2004 on the elimination of Domestic Violence. 
However, they do not agree in other forms of violence to be defined as domestic violence, one of them is the sexual violence and marital rape.

Meanwhile, survivors of domestic violence in Makassar define domestic violence to several types. The first is physical domestic violence as beating, hitting, slapping, punching, choking or fighting during an argument. The most common forms of physical abuse committed by husbands is beating using metal bar or wood (known as balo-balo) and slapping to the face. Thus, any physical attack is considered as physical violence. The second is psychological abuse as any action which leads to emotional instability, such as intimidations to physical harm or threats of murder, swearing, and intervention from other family members, accusing others of having affairs, reluctance to share domestic responsibilities, and anger or bad temper. The third is verbal violence which include accusation of having affairs, polygamy, spitting, yelling, undermining and name-calling, including calling the victims with humiliating names such as stupid, sundala (whores or prostitutes), and perempuan sial (cursed woman).

The fourth is economic abuse. This abuse can be the reluctance of the husbands to provide financial support for the family, restrictions on personal spending, and financial deprivation or financial control. This kind of violence is related to social factors, including poverty or unemployment, and personal factors such as meanness. One abused woman admitted, "I am not allowed to manage the family budget. My husband keeps questioning on how I spent the money if there is not enough money to pay bills or food". The last is sexual violence. However, this violence is rarely spoken, and there are only two women during the research that brought up the issue. This is not so surprising because matters related to sex is still taboo in Indonesia moreover if it is a matter of sexual abuse within the marriage. Examples of sexual violence, which could be described as marital rape, are told by these two women. They told how their husbands had tried to force them to engage in sexual relations, including during menstruation.

In response to these types of violence, those survivors react differently. The most common reaction is acceptance. Survivors often feel that such violence is 'their fault'. They accept such violence because they are fearful that they will be blamed by their extended family. In Indonesia, to expose family matters to public, including to police officers or NGO activists, is simply not best interest for the family in. Thus, they choose to be 'passive' in addressing the violence 
and considered powerless in this cultural setting. They believe that those unfortunate things happening between them and their husbands are commonplace and they considered them as private matters of or family matter. ${ }^{5}$ Unwillingness to disclose harmful violence was common due to pressure to maintain siri' (family honor), and preserve the family structure for the sake of children. Likewise, those poor wives believe that it was inappropriate to disclose a husband's violence publicly.

\section{Factors behind the domestic violence}

There are several factors and reasons contributing to the occurence of domestic violence in Indonesia. In Makassar, domestic violence often occur only because of attempts to challengee and question men's power and authority. This includes woman's attempt to advise men to adhere to religious and cultural values and norms such as abstinence from alcohol, abstinence from having sexual affairs, encouragement to seek for employment, or even responding to a man's anger or accusation during an argument. Here, women's attempt to guide men or to negotiate with them are perceived by the men as an act to undermine them and threaten their designated position in the family which is ascribed by the society. Other reasons are infidelity in marriage and polygamy, gender division of labor, financial issues and alcohol. $^{6}$

Therefore, women's perceptions on domestic violence are various. What ironic is the fact that these survivors often assume that domestic violence is permitted for certain circumstances and here they base their acceptance on religious justification. Obviously, this view needs to be critically questioned and examined. Therefore, domestic violence should be seen as a social, political and legal issue. ${ }^{7}$ This study attempts to locate domestic violence within cultural, legal or government policies, and religious frameworks, specifically Islam, to consider how

\footnotetext{
${ }^{5}$ RS Kalibonso, Kekerasan Rumah Tangga Mencapai 70 Persen, (Kompas, October $5^{\text {th }}$, 2002); See also: F Irdianto, „Kekerasan Terbadap Istri dan Respons Masyarakat, in AN Abrar and W Tamtiari (eds.) Konstruksi Seksualitas: Antara Hak dan Kekuasaan, (Pusat Penelitian Kependudukan Universitas Gajah Mada: Yokyakarta, 2001), p. 57.

${ }^{6}$ Interview with several women as survivors of domestic violence in Makassar, March 2004.

7 MA Dutton \& EE Gondolf, "Wife Battering," in RT Ammerman \& M Hersen (eds) Case Studies in Family Violence, 2nd edition (Kluwer Academic: New York, 2000), p. 323.
} 
gender relations are constructed within these discourses, and how such relations produce and reproduce domestic violence. This approach attempts to respond to Bennett and Manderson's statement that: 'the cultural, religious and institutional factors that promote or condone violence against women can remain unchallenged despite progress in terms of economic development'. ${ }^{8}$

\section{Domestic Violence: Muslim Scholars versus Muslim Feminists}

Theoritically, theological underpinnings of Islam respects human rights, that is based on love and solidarity, and acknowledges that men and women are similar with respect to moral, spiritual and intellectual capabilities. Both men and women can exercise these capabilities independently. One of the most fundamental islamic principles is that a person's value is based on the taqwa. Here, a person's value is not determined by gender, race, social status or other factors. These are clearly stated in the Qur'an where the principal resources for Islamic teachings underline the idea that every individual is a trustee (Q. 2: 30), equal in the order of creation (Q. 4: 1; 7: 189; 32: 28; 6: 45, 53), and a partner in community affairs (Q. 50: 21). However, many contemporary Western debates and understandings of Islam undermine these fundamental Islamic principles by claiming that Islam is a religion which oppresses women as well as condones violence including terrorism and domestic violence. This perception can be partly associated with, and supported by, misleading information or 'misinterpretations' on Islamic teachings either by secular thinkers or by the muslims themselves ${ }^{9}$ including community leaders, elders, individuals and religious leaders (imäms). These people do not only misinterpret the Qur'an against its spirit, they also promote this interpretation often to support personal or political agendas.

It is commonly assumed among Muslims that men have the right to 'educate' women who are under their guardianship. More specifically, many believe that a husband has the right to punish his wife in certain circumstances such as nushüz, which literally means 'disobedience'. There is no consensus among Muslim scholars about

${ }^{8}$ LR Bennett \& L Manderson, 'Introduction: Gender Inequality and Technologies of Violence', in L Manderson and LR Bennett (eds.) Violence Against Women in Asian Societies (Routledge Curzon: London, 2003), p. 4.

9 Yahiya Emerick, The Complete Idiot's Guide to Understanding Islam, 2nd edition (USA: Penguin Group, 2004), pp. 270-271. 
definitions or boundaries of 'disobedience'. The definition and the boundaries on what can be defined as disobedience then depend on individual interpretations. This is clearly true at least in Makassar as revealed from the interviews with both female and male Muslim scholars. In addition, this is also shown from various literatures of the Qur'anic scholars. For example, a literal interpretation of the verse (Q.S. 4: 34) allows a husband to use physical punishment for a noncompliant wife within certain limitations.

Husbands [al-rijā $]$ should take full care of their wives [qawwamun], with (the bounties) God has given to some more than others and with what they spend out of their own money. Righteous wives are devout [qänitat], and guard [bafiza $\bar{a}$ t] what God would have them guard in their husbands' absence. If you fear high-handedness from your wives, remind them (of the teachings of God), then ignore them when you go to bed, then hit them [wa idribūhunna]. If they obey you, you have no right to act against them: God is most high and great. ${ }^{10}$

There are several key terms should be explained in relation to this verse. In the case of women's leadership, the terms that have been used to support an understanding of male supremacy or male leadership are al-rijal and qawwamin ${ }^{11}$ which are often translated into 'men' and 'the maintainers or protectors' respectively. In the Indonesian Qur'anic translation from the misnistry of Religious Affairs of Indonesia, qawwämūn means 'leaders'. Different commentators have different interpretations of those terms that are apparently influenced by their cultural, social and geographical locations.

The term al-rijal is controversial because it can be translated as 'men' in general or can be limited to husbands. A prominent Indonesian Qur'anic commentator, Muhammad Quraish Shihab, quotes another Qur'anic scholar, Muhammad Ṭāhir bin Ashūr, notes that this term refers to all men rather than referring exclusively to husbands. This translation is mostly used in the Qur'an as well as in Arabic literature. So, the phrase al-rijāl qawnāmūn 'alā al-nisà' (translated

\footnotetext{
10 Abdel Haleem, The Quran (Oxford: The University Press, 2005), p. 54.

${ }^{11}$ Qawwamun is a plural form of qawamah. The word qawamab is sometimes also written as qawwamah. All have a similar meaning: leadership in terms of protectors and maintainers.
}

$\mathbf{5 4} \mid$\begin{tabular}{l|l} 
JOURNAL OF INDONESIAN ISLAM \\
VOLUME O6, NUMBER O1, JUNE 2012
\end{tabular} 
as men as the leaders over women) acts as an introduction to the next phrase of the verse pertaining to the characteristics of good wives. ${ }^{12}$ Here, some Muslim scholars have used this verse or this intepretation of the verse to justify the exclusion of women from holding government positions. This is evident in Indonesia in case of Megawati when she fought for precidency. The verse, along with the interpretation, is used to challenge Megawati's Presidential candidature. Conversely, the term al-rijal can refer to husbands to indicate that husbands are the principal providers or heads of family because the rest of this verse describes prescribed roles of husbands and wives within marriage relations.

Another problematic word which has stimulated controversy is qawwämun. In this regard, Engineer notes that conservative scholars interpreted this term as 'a man is like a police officer for woman', while modern commentators such as Muhammad As ad understood this in a more flexible way, but still placed men in control of women. As `ad, according to Engineer, argued that qawnamūn does not emphasis male domination over women, but merely men's responsibility or obligation to take care of women with respect to financial maintenance and protection as well as to moral or religious responsibility. ${ }^{13} \mathrm{~A}$ wellknown Qur'ànic commentator, al-Zamakhsharì (d. 1074 CE), translates qawwa amun as 'men are in charge of the affairs' of women, arguing that this occurs because men have been given 'preference' by God over women with respect to intelligence, physical constitution, determination and physical strength. These traits are considered as primordial nature (fitrah). ${ }^{14}$

In a similar vein, Shihab argues that qawwamun means leaders; that men are leaders over women whether in family or in the wider contexts. He further puts forward an argument that men are more appropriate leaders than women for the following reasons. One is that the Qur'anic text describes that bi mà faddala Allāh ba'dabum 'ala ba'd ('Allāh has given more strength to the one [men] than the other

12 M. Quraish Shihab, Tafsir al-Misbah: Pesan, Kesan dan Keserasian Al-Qur'an, vol. 2 (Jakarta: Lentera Hati, 2002), p. 404.

13 Ali Asghar Engineer, The Qur'an, Women and Modern Society (India: New Dawn Press Group, 2005), pp. 48-49.

${ }^{14}$ Abū al-Qạsim al-Zamakhsharì, Tafsìr al-Kashshäf, Vol. 1 (Beirut: Dār al-Fikr, 1977), p. 523. 
[women]). In interpreting this phrase, Shihab refers to views from psychologists and others to demonstrate that there are physical, intellectual and emotional differences between men and women. For Shihab, therefore, both men and women have their own distinctive traits, but men are more adept at taking leadership responsibilities in terms of financial support and the protection in the form of economic and physical care. Conversely, women have special capabilities to educate and raise children. ${ }^{15}$ Shihab's interpretation certainly offers specific features that underpin a gender division of labour within both the public and private realm. This in turn shapes gender relations in both spheres. Shihab also argues that the term faddala (Allah has preferred or made) means that Allah has given men preference in exercising leadership or authority. To support this understanding, male Qur'anic commentators sometimes refer to another Qur'anic verse (Q: 228) where the term darajah (literally meaning degree or position) contends that men have higher positions or more privileges than women. Shihab envisages that darajah refers to a husband's generosity to his wife in assisting with her responsibilities. Unfortunately, Shihab does not clarify such responsibilities but he then quotes a medieval Muslim scholar, At-Ṭabari (d. 923), who argues that a husband can achieve darajab if he treats his wife wisely. ${ }^{16}$

Another Qur'anic commentator, al-Rāzi (d. 1209 CE), interprets the term faddala as male superiority by referring to the social and cultural fact that men have more knowledge and skills than women. To illustrate this, he argues that men can hold political office, can be Prophets and religious leaders and receive larger inheritances. Consequently, men are more appropriate to be qawwamunn. ${ }^{17} \mathrm{Al}-\mathrm{R} a \bar{z} \bar{i}$ does not acknowledge the degree to which the socio-cultural apparatus produces men's superiority.

The second reason which supports men's roles as leaders is the Qur'anic phrase: bi mā anfaqu min amwälihim (because they support them from their means). Shihab asserts that men are capable to lead the family because they provide economic support as reflected in many social and cultural contexts. Shihab supports his account by referring

\footnotetext{
${ }^{15}$ Shihab, Tafsir al-Misbah, pp. 405-407.

16 Ibid., pp. 408-409.

${ }_{17}$ Muḥammad Fakhr al-Rāzi, Tafsìr Fakhr al-Rāị̦i, Vol. 3 (Beirut: Dār al-Fikr, n.d.), p. 91.
} 
to the psychological impact of changing or reversing the gender division of labour. ${ }^{18}$

It can be argued that Shihab tries to confirm traditional interpretations which emphasize the position of women in the family as domestic careers and is reluctant to acknowledge that women may lead the family if they support their family economically. Although Shihab identifies specific gender roles and responsibilities he emphasizes that men should be democratic within marriage in performing a leadership role. ${ }^{19}$

These interpretations invoke critical responses from contemporary Muslim feminists such as Azizah al-Hibri, Amina Wadud and Nimat Hafez Barazangi who question such understandings of the Qur'anic texts. Al-Hibri asserts that the Qur'anic verse (Q. 4: 23) does not actually support male supremacy over women in all situations and contexts, but that male leadership is conditional. Men can be qawnamin or 'women's guardians' if they fulfill two requirements: the first is when men have been given more than women (preference) and this preference, according to Wadud, relates to inheritance; the second is that they should support women from their wealth, ${ }^{20}$ including the giving of dowry (mahr) and maintenance (nafaqah). ${ }^{21}$ Thus, if the men fail to meet these responsibilities, they certainly cannot be qawwamun.

In a similar vein, a male Indonesian Muslim scholar who supports gender equality, Nasaruddin Umar, argues that not all men are qualified to be qawwamin or to achieve darajah as these terms begin with a specific Arabic form al-rijäl (ma'rifah/definite - article) which means that there are certain men who have the capacity to fulfill domestic responsibilities. ${ }^{22}$ Moreover, an interesting interpretation from a modernist male Qur'anic commentator, Muhammad 'Abduh (d. 1905

\footnotetext{
18Shihab , Tafsir al-Misbah, p. 408.

19 Ibid.

20 Aziza al-Hibri, 'A Study of Islamic Herstory: Or How Did We Ever Get Into This Mess?,' Women's Studies International Forum, vol. 5, no. 2 (1982), p. 218; Amina Wadud, Qur'an and Woman: Rereading the Sacred Text from a Woman's Perspective (New York: Oxford University Press, 1999), p. 70; Etin Anwar, Gender and Self in Islam (New York: Routledge, 2006), p. 46.

21 Al-Zamakhshari, Tafsìr al-Kashshäf, p. 524; see also Al-Rāzi, Tafsìr Fakhr al-Rā̄̄i, Vol. 10, p. 91.

22 Nasaruddin Umar, Argumen Kesetaraan Jender: Perspektif al-Qur'an (Jakarta: Paramadina, 1999), p. 149-150
} 
CE), points out that not every man is qawnamun because the following phrase in the verse bi ma faddala Allah (preference) indicates that both men and women have their own privileges and functions, so no one can declare that the men are more important or more valuable than the women because both of them are inter-dependent. He illustrates this point by referring to the function of the human body in which, for example, man is the head and woman is the heart, or other parts of human anatomy. His point is that the anatomy works together to sustain a healthy body, so it is difficult to claim that a part of the body contributes more than any other part. Meanwhile, 'Abduh also notes that the Qur'an uses the term bi mā faddala Allāh ba'dahum 'ala ba'd, which identifies the possibility of both men and women being qawnamin because they have complementary roles and responsibilities, rather than the use of term bi má faddalahum 'alaybinna or bi tafdịilibim 'alaybinna which specifically gives men such privileges. ${ }^{23}$ Thus, it is clear that here the conservative arguments in relation to men's superiority over women and leadership initiatives are challenged such that women can also be called qawwamun (protectors, maintainers or leaders) if they have the skills and resources to lead in both the public and private spheres.

Barazangi argues that interpretations of the Qur'anic verses (Q. 4: 34 and Q. 2: 228) which refer to men's guardianship of and superiority over women, particularly in terms of moral guidance, have significant implications for women. This has resulted in subsequent generations of women having lost their self-identity within Islam. The argument that women merely undertake secondary roles is challenged by Barazangi who refers to such interpretations as offering a 'proxy religio-morality', which means that women are expected to obey male interpretations as they only have proxy role. ${ }^{24}$ Such expectations are internalised in women's beliefs. Yet, this expectation is inconsistent with the spirit of Islam which asserts that every individual has a right to trusteeship (khilafah). Barazangi goes on to clarify the two key concepts which have led to controversy: qawnamin and darajah. ${ }^{25}$ She argues that qawwamun only refers to male economic responsibilities in

${ }^{23}$ Muḥammad 'Abduh, Tafsìr al-Manār, Vol. V (Egypt: Al-Manār, 1328), pp. 67-69.

${ }^{24}$ Nimat Hafez Barazangi, Woman's Identity and the Qur'an: A New Reading (Gainsville: University Press of Florida, 2004), p. 52.

25 Ibid., p. 52-53. 
the family vis-à-vis women's biologically important role of procreation. The term darajah referring to the question of privilege among men and women means 'God has bestowed differently among individuals', which merely indicates an additional responsibility for man if he initiates divorce. The relationship between the two verses, Islamic justice and human complementary roles is described further in the verse (Q. 4: 32) which states that both men and women are personally accomplished. Thus, Barazangi argues that the Qur'an neither identifies certain responsibilities between men and women nor makes generalisations about them with respect to other intellectual, moral and social responsibilities. Human beings are created for different purposes, but within biological functions they are inter-dependent. ${ }^{26}$ For Wadud, the Qur'an prescribes the biological function of the mother (women) as child bearing, but it does not prescribe the psychological and cultural perceptions of 'mothering', ${ }^{27}$ including the relegation of women to the private sphere. It is clear that there is no difference between men and women with respect to intellectual, moral or social and political roles within the Islamic teachings. For Wadud, the difference between men and women merely refers to the biological function of women in child bearing.

In addition, the verse (Q. 2: 34) recommends the development of a collective and balanced community. Wadud asserts that qawwamun does not exclusively refer to men's supremacy because contemporary social and economic conditions show that women also contribute to family income and in some instances they can be the primary economic earners due to a husband's incapacity or other factors. She notes that this verse aims to constitute a fair and just society. 28

A sharing and complementary society or family is essential to achieving equality, and no specific gender has more privileges than the other. The lesson learned from the verse is that Islam allows a distribution of labor or cooperative management skills based on personal qualifications and capabilities, rather than on gender. This verse is, therefore, not gender normative. Clearly, women who have more capabilities and opportunities to hold leadership roles both in the community and the family can be qawwaminn, and men (husbands) need

\footnotetext{
26 Ibid.

27 Amina Wadud, Qur'an and Woman, p. 22.

${ }^{28}$ Ibid., p. 73-74.
} 
to accept such realities without considering it a social and cultural stigma. According to the verse (Q. 4: 124), women's endeavours for the development and the well-being of the community as well as for the family will be rewarded by God in the same way as men. Again, no clear Qur'anic message stipulates that men are suitable and capable for leadership roles in public life and for the guardianship of women in the private sphere.

Moreover, the verse (Q. 4: 34) is understood to justify physical chastisement against a 'disobedient' wife. It is presumed that the physical abuse of a wife is a means of last resort to resolve marriage conflict after other educational or psychological actions such as giving advice or sleeping apart have been attempted. The Qur'anic text stipulates:

...Righteous wives are devout [qānitat], and guard [häfižăt] what God would have them guard in their husbands' absence. If you fear high-handedness from your wives, remind them (of the teachings of God), then ignore them when you go to bed, then hit them [wa idribübunna]. If they obey you, you have no right to act against them: God is most high and great. ${ }^{29}$

Two prescriptions of good women: obedient (qänitāt) and guard the unseen (ghayb) as Allah has guarded. If a husband fears his wife's desertion (nushī $\bar{y}$ ), admonish her, and leave her alone in the bed and chastise them (wa idribūbunna). There are two fundamental problems with this account concerning what a 'good wife' is and how the husband should act if his wife is not 'being good' or nushī: disloyal or rebellious. These two problems are interrelated because the definition of a good wife for one person may differ from that of another person, so that a justification for whether his wife is disloyal or not is personal, subjective and male-defined. A 'good woman' is described as qānität and buafizăt.

The term qānitāt has various interpretations. Al-Rāzi, for example, translates qanitat as women's obedience to Allah in which it is understood that good women obey Allah's commands. ${ }^{30} \mathrm{Al}$ Zamakhshari, however, interprets the term 'obedient' wife to mean

\footnotetext{
${ }^{29}$ Haleem, The Quran, p. 54.

30 Al-Rāzi, Tafsìr Fakhr al-Rǟì, vol. 10, p. 91.
} 
that the wife must obey her husband. ${ }^{31}$ Another prominent Qur'anic commentator, 'Abduh, points out that qanitat is translated into the wife's obedience to God as well as to husband 'for good purposes only'.32 'Abduh's argument should be interpreted in the contemporary context in which submission and obedience to a husband is limited to certain acts that do not contravene Islamic teachings such as performing religious practices, respecting others, and tolerance. These should be based on women's (wives) agreement, understanding and choice. This is important to highlight because every woman has a different interpretation of Islamic teaching which determines the choices they make. It should be emphasised that it is an individual's right to interpret the Qur'an, particularly specific terms that have no clear explanation in the Qur'an and the Prophetic traditions. Thus, to transform the Qur'anic term of qanitat in the contemporary social and cultural context, this term should be translated into two different aspects: 'obedience' to God, and respect for her husband, as the status of God and a husband is different. In Indonesia, at least in Makassar, very few women accept this view, and most women's perceptions and cultural preconceptions of the good woman seem to be predicated on al-Zamakhshari's argument that a wife must obey her husband. ${ }^{33}$

According to women activists, survivors of domestic violence and religious leaders in this field study, a good wife is culturally defined as dutiful in domestic chores, willing to stay at home, loyal, tolerant (even to violence), respectful and this includes giving priority to a husband to eat before other family members. ${ }^{34}$ These cultural constructions have been internalised within the women, particularly abused women.

Survivors of family violence offer different accounts of what constitutes 'a good wife'. For instance, one woman notes that a good wife 'always provides meals for her husband, cooks and washes clothes'. ${ }^{35}$ Another respondent believes that a woman who cares for

\footnotetext{
31 Al-Zamakhshari, Tafsìr al-Kashshäf, vol. I, p. 524.

32 'Abduh, Tafsir al-Manār, vol. 5, p. 70.

33 Al-Zamakhshari, Tafsìr al-Kashshäf, vol. I, p. 524.

34 All respondents were asked about 'a good wife' according to their culture, and the responds are summarised as mentioned above.

35 Author's interview with S 01, in Makassar (March 4th, 2004). Some survivors such as S 14 and S 15 have similar accounts that constitute 'a good wife'. Author's interview with S 15 and 16 in Makassar (March 16th and April 10 th, 2004 respectively)
} 
her children and husband, and has mutual respect is considered a good wife. ${ }^{36}$ Women's prescriptions of a good woman are a result of social and cultural constructions in which women's primary role is conceived in terms of caring for family members and performing domestic chores. However, some women survivors of domestic violence also highlight features of being a good wife which are not merely related to the role of domestic carer, but configure the wife's role as family adviser. One woman said: 'a good wife is a woman who respects her husband, maintains his dignity, and she should advise or challenge him with respect to his misconduct'. ${ }^{37}$ Another woman responded to a question about what constitutes a good wife emphasising the following attributes:

Do not let your husband undermine you, do not just give him what he wants in the bed and in the kitchen; [a wife must also] take care of children, teach her husband to be a good person and guide him about his misconducts and wrongdoings. 38

As can be seen here, a good wife can be both domestic carer as well as advisor. She is also able to perform other duties, not just around 'the kitchen and in the bed'. This interviewee tries to challenge the common belief of the community that the most important role for women is to satisfy the husband's sexual needs, as well as to know how to cook or undertake jobs in the kitchen. She begins using a powerful phrase: 'do not let your husband undermine you...' which implies that she lets other women know that a good wife's value is not exclusively limited to her domestic attributes, but also in mastering other skills that may be considered as male or pertaining to men. As part of this self-empowerment, the 'good' wife should also be able to coach her husband to live responsibly and act ethically. In addition, one woman asserts that obeying fair requests from her husband can also be understood as being a good wife. ${ }^{39}$

Another feature of the 'good wife' within the Qur'anic text is

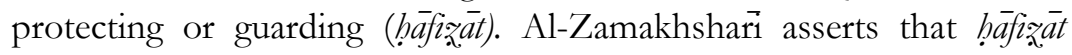
concerns a woman who can take care of herself, faithful and maintain

\footnotetext{
36 Author's interview with S 05 in Makassar (March 4th, 2004)

37 Author's interview with S 12 in Makassar (March 15 th , 2004)

38 Author's interview with S 17 in Makassar (March 25 th, 2004 )

${ }^{39}$ Author's interview with S 04 in Makassar (March 4th, 2004)
} 
the house and other properties while her husband is away..$^{40}$ Moreover, 'Abduh argues that a good wife is a woman who conceals information or attitudes to other people whether with respect to family and marriage relations or other issues. ${ }^{41}$ 'Abduh's argument concerns a privacy issue: that is, the good wife keeps personal issues within the family. However, a woman who discloses abuse perpetrated by her husband to police or another related agency in order to seek intervention, should not be prevented from doing so under the categorisation of hâfiza $\overline{a t}$. So, the woman can still be considered as a 'good wife' or haffia àt even if she discloses family violence.

The next question concerns how a husband can act in response to his wife's disloyalty (nushī explains that husbands who fear desertion (nushü), can admonish wives, withdraw from bed and chastise them (wa idribübunna). There are various interpretations of this verse, and explanations of certain terms follow. According to one Qur'anic commentator, Al-Qurtubi (d. 1273 CE), nushuz means that the wife has failed or is reluctant to obey her husband as God has commanded. ${ }^{42}$ Al-Razi cites the well-known Islamic jurist, al-Imām al-Shäfi' $\overline{1}$, ascribing that there are two forms of nushü verbal and behavioural. Thus, nushü can include a wife's failure to respond to a husband's call, or not listening to the husband's criticism by promising to do things as he wishes. Another way of nushü is through physical resistance which includes refusing to have sex with her husband or doing something against her husband's will. ${ }^{43}$ These views illustrate that there are no clear guidelines to follow in establishing exactly when a wife should be considered 'rebellious or disloyal'. It depends on who defines the term as revealed from the commentators' examples which are certainly influenced by their social and cultural values and, as such, this is very subjective.

On the other hand, some Muslim scholars in Makassar offer progressive arguments with respect to the term nushiz. One Muslim scholar, for instance, notes that nushiz may refer to a wife's refusal to

\footnotetext{
40 Al-Zamakhshari, Tafsìr al-Kashshäf, vol. I, p. 524.

41 'Abduh, Tafsir al-Manār, vol. 5, p. 71.

42 Muḥmmad bin Aḥmad al-Qurțubi, Al-jāmi' Li Aḅkam al-Qưr'an, Vol. 5, (n.d.), pp. 170-171.

${ }^{43}$ Al-Rāzi, Tafsir Fakhr al-Rä̌ì, vol. 10, p. 92.
} 
respond her husband's sexual needs, but religious teachings allow for the denial of sexual intimacy due to tiredness, for example. A wise, fair and just husband would accept his wife's circumstance and not force her to have sex even though he has this right as a husband, and the wife has also the right to refuse it. ${ }^{44}$

Moreover, in an interview with a female religious scholar with respect to nushiz, she argues that this term varies from one culture to another, depending on the individual or community perceptions and values. To illustrate this, some may believe that a married woman who talks to another man is considered as nushīz, while others may not. So, the standard depends on individual and community beliefs and values. ${ }^{45}$ Here, it is important to highlight that both husband and wife should have an agreement about what nushiz means in the context of their marital relations to avoid serious conflict or what Wadud has called a 'disruption of marital harmony'. 46 Among all the points of views, the most appropriate definition of nushuz is the occurence of disagreement or conflict between husband and wife (marital conflict), the suggested definition by Wadud. If marital conflict is evident, according to the Qur'an, there are three methods to redress it, namely 'intensive discussion' (fa 'idhü hunna); 'separate beds' (fa ubjuru bunna); and 'chastisement' (wa idribü bunna).

The first solution is through 'intensive discussion' ( $f a$ 'idhü bunna). Discussion between husband and wife is important to allow the wife to provide her versions of events in line with the doctrine of nushiz. The wife is also free to give reasons without being pressed or blamed, and her voice should be heard because the main purpose of this discussion is to resolve any conflict or disagreement. Although the literal meaning of the term fa 'idhü hunna is 'advise them (wives)', this can be understood as 'intensive discussion' because it offers women the chance to be actively involved in the resolution as well as empowering them. This understanding is also relevant to Wadud's concept of 'mutual consultation'47 and Sayyid Qutb's (d. 1966 CE) concept of

\footnotetext{
${ }^{44}$ Author's interview with a Religious scholar, RS 01 in Makassar (March 19th 2004).

45 Author's interview with RS 03 in Makassar (March 18 $\left.{ }^{\text {th }}, 2004\right)$.

46 Wadud, Qur'an and Woman, p. 74.

${ }^{47}$ Ibid.
} 
'verbal solution', but Qutb insists that a verbal solution can be initiated by the couple or in the presence of arbiters. ${ }^{48}$

However, these interpretations are quite different from classic commentators such as al-Qurtubi ascribing that the husband should advise his wife to fulfil her responsibilities to obey him as narrated in Prophetic traditions (ahä $\overline{d i t h}$ ) from different resources (transmissions). Al-Qurtubi quotes the Prophet Muhammad's words 'If I would have ordered anyone to bow down to anyone I would have ordered a wife to bow down to her husband', in support of this view.49 Al-Qurțubi's view clearly implies the importance of a wife's obedience to her husband, but ignores the fact that the Prophet's words are conditional in this respect. Moreover, if intensive discussion fails, further steps should be taken.

The second way to resolve marital conflict is through 'separate beds' (fa ubjuru hunna) which is literally translated as 'banish them to beds apart'.50 The Qur'anic scholars (mufassir) have various interpretations of this term. Al-Qurtubi and al-Zamakhshari, for example, include the concept of 'separate beds' refusing to talk to the wife, sleeping apart from her and refusing to have sex with her. ${ }^{51}$ The purpose of this kind of psychological pressure is that it expects husband and wife to resolve their marital problems and reflect the difficulty of their marriage without communication. This stage, according to Wadud, is called a 'cooling-off period'.52 If a second resolution is not reached, then the final resort should be taken, that is 'chastisement' (wa idribü hunna).

The term wa idribü bunna as the ultimate solution for resolving marital conflict and is interpreted through two approaches, literal and contextual. Literally, this term is understood to allow a husband to physically punish his wife within very limited circumstances. Most Islamic scholars and Muslim commentators uphold this view. For instance, Quṭ argues that only light chastisement is permitted and this

\footnotetext{
48 Sayyid Quṭb, Fī Dhilāl al-Qur'an, Vol. 2 (Egypt: Dār al-Shurūq, 1980), p. 653.

${ }^{49}$ Al-Qurțubi, Al-jämi' Li Aḅkāam al-Qur'ān, vol. 5, no. 3, p. 171.

50 Wadud, Qur'an and Woman, p. 75.

51 Al-Qurțubì, Al-jami' Li Aḅkāam al-Qur'ān, vol. 5, no. 3, pp. 171-172; al-Zamakhshari, Tafsir al-Kashshäf, vol. I, p. 524.

52 Wadud, Qur'an and Woman, p. 76.
} 
should not leave any physical mark because this is 'un-Islamic'.53 Another medieval Qur'anic commentator, al-Qurtubi, translates this term as 'educative punishment' which means that husband is allowed to strike his wife when she does not comply with the first and second solution to redress marital conflict as previously described, but he should avoid violence. He elaborates his argument by quoting various abadith which justify that the chastisement occurs only once, or involves the use of implements such as a 'toothbrush'. ${ }^{54}$ Similarly, alRazi argues that physical punishment is a resort utilised in a situation of crisis and a husband should first attempt to persuade his wife to halt the nushiz by applying other methods. He refers to another Muslim jurist, al-Shäfi'i, who argues that physical punishment is allowed but prevention is preferred. Al-Räzi also quotes the Prophet's companions' views in relation to methods of physical punishment: in order to avoid hurting the wife, items such as using handkerchiefs could be used, but items of physical punishment such as whips are forbidden. ${ }^{55}$

These Qur'anic commentators agree that physical violence should be avoided, but beating is permitted if men refrain from brutality by using toothbrushes or handkerchiefs. This constitutes symbolic chastisement. Such an approach is no doubt due to the commentators' literal understanding of the Qur'anic texts as well as the influence of their local cultural location, practices and attitudes. The Qur'an was initially revealed in Arab society when patriarchal practices were very strong and systematic. Women in many instances had few legal, social and political rights. Physical chastisement of wives was also a common way to discipline a 'disobedient wife' within this community regardless of the perpetrator's social stratification or religious background. Thus, domestic violence was considered permissible and justifiable. ${ }^{56}$ This strong cultural practice of wife abuse undoubtedly influenced the Qur'anic scholars' connection of arguments permitting domestic violence to the Hadith or other methodological approaches in understanding Islamic teachings, including legal reasoning (ijtihäd) from the prophet Muhammad's companions (sabăbab), which can represent

\footnotetext{
${ }^{53}$ Quṭ, Fì Dhiläl al-Qur'an, p. 653.

54 Al-Qurtubi, Al-Jämi' Li Aḅkām al-Qur'an, vol. 5, no.3, p. 172.

55 Al-Rāzi, Tafsìr Fakehr al-Rä̌̀i, vol. 10, p. 93

${ }^{56}$ Engineer, The Qur'an, Women, p. 55.
} 
specific personal, social and cultural settings. It is clear that commentators who interpret the term wa idribu hunna (punish wives) textually, generally use Qur'anic sources to allow wife beating within very limited circumstances.

This interpretation is widely shared by hierarchical gender-minded Muslim scholars both male and female, intentionally or accidentally. Indonesian Qur'anic scholars like Shihab share similar views in perceiving that the term wa idribu hunna is understood to mean that a husband can beat his wife within certain conditions which limit chastisement to that which results in no physical harm. Shihab insists that beating should only be an act of last resort resulting in situations in which intensive discussion and separate beds have failed to resolve marital conflict. He also notes that beating is not an appropriate solution among well-educated husbands in contemporary society. ${ }^{57}$ However, male and female Muslim scholars from Makassar whom I interviewed did not offer a radically different understanding from that of classical Qur'anic commentators. The crux of their view is that chastising a disloyal wife should only be used as a last resort and should not leave any physical marks. ${ }^{58}$ Intensive discussion and separation are preferable to resolve family matters, and physical discipline is acceptable only if it does not cause bodily injury.

This restriction on chastisement as physical punishment, however, is apparently often understood differently for some Muslims, particularly abused women. They believe that Islam entitles a husband to beat his wife if she does not fulfill her wifely roles and responsibilities or if she fails to submit to his will. Some women assert that it is justifiable to beat or even to murder a wife who is unfaithful, as one survivor of domestic violence stated: 'a husband is allowed to beat or even kill his wife if she is unfaithful'. ${ }^{59}$ Another survivor asserted: 'a husband can beat his wife if she really made mistakes like infidelity, or was reluctant in providing food and clothing for her husband'.60 These accounts demonstrate that women believe a husband is entitled to physically punish his wife for infidelity or failure

\footnotetext{
${ }^{57}$ Shihab, Tafsir al-Misbah, p. 411.

58 Author's interview with RS 01, 02 and 03 in Makassar (March 19 ${ }^{\text {th }}, 18^{\text {th }}$ and April $8^{\text {th }}, 2004$ respectively).

59 Author's interview with S 01 in Makassar (March 4th, 2004).

${ }^{60}$ Author's interview with S 05 in Makassar (March 4th, 2004).
} 
to take care of his needs. Other reasons for wife beating, according to a survivor of domestic violence, include wrongdoings such as 'ignoring her husband's good requests'. ${ }^{61}$ These women's accounts reflect the interconnection between textual understandings of the Qur'an and women's beliefs which result from social and cultural constructions. Sadly, these women tend to accept men's violence against women.

However, contextual approach can be used to interpret the Qur'an or Islamic texts in order to challenge patriarchal conspiracies as well as to allow gender justice. Some Muslim scholars including Muslim feminists argue the term wa idribu bunna must be contextualized in the context of modern and global society because this is more relevant to the underlying message of Islam and more appropriate to human rights and gender equality. A progressive Qur'anic commentator, 'Abduh, for example, asserts this term should be translated in other meanings (ta'wi) rather than physical chastisement as mostly translated by traditional scholars for a number of reasons. Firstly, the main principle of marriage in Islam is to achieve a happy and harmonious family (mawaddah wa rahmah), and both husband and wife should be cooperative. Love and mutual respect are important in achieving this aim. Secondly, Islam teaches men (husbands) to be respectful, affectionate, wise and kind towards their wives, and discourages violent behaviour. 'Abduh cites various ahadith which contend that it is shameful if a husband chastises his wife as he chastises his slave in the morning, then lies with her in the evening', and 'a husband who never beats his wife is the best'. ${ }^{62}$ In this context, 'Abduh rejects the classical interpretation of the term wa idribu bunna as beating, but in suggesting that there should be a different interpretation, fails to provide it. At least he has generated a new paradigm of Qur'anic interpretation in an era where traditional and exclusive interpretations of the Qur'an have been so persistent. It can also be understood from 'Abduh's rejection that the use of violence indicates men's weaknesses rather than their strengths, as they have failed to communicate effectively or to resolve differences with their partners.

Similarly, Muslim feminists such as Engineer and Wadud disagree with the classical understanding of the term wa idribu hunna as beating or physical punishment, but they do not clearly define an alternative

${ }^{61}$ Author's interview with S 04 in Makassar (March 4th, 2004).

62 'Abduh, Tafsìr al-Manār, vol. 5, p. 75. 
meaning to this term. Rather, they highlight various arguments from selective materials of the Qur'anic commentary to elaborate that physical punishment is not intended in the Qur'an. ${ }^{63}$ Conversely, some Muslim scholars have offered other interpretations of the term wa idribü bunna, citing its original form daraba. ${ }^{64}$ Rather than beating, they advocate sexual intercourse. Nasaruddin Umar, argues that the term should be translated as sexual intercourse as this term encompasses different meanings including 'mixing up something' and 'travelling'. ${ }^{65}$ Similarly, Ahmad Ali of Pakistan, quoted in Engineer, supports Umar's view. ${ }^{66}$ Umar also suggests that the lexical translation of wa idribú bunna into physical chastisement is incompatible with the purpose of marriage in Islam which is to build a happy and harmonious family. ${ }^{67}$ Rather, the three ways that a husband can resolve marriage conflicts, consist of discussion, followed by taking separate beds, and finally having sex.

I would argue that although the word daraba can be translated into sexual intercourse, it is logically unacceptable within this context for two reasons. Firstly, this understanding is contrary to the second solution of taking 'separate beds' which requires abstaining from sexual intercourse. If this second form of resolution disallows sex, it does not make sense that the third suggestion would be to reinstate sexual relations. The second reason for rejecting the translation of wa idribu bunna as sexual intercourse concerns the wife's emotions. If the wife is angry and disagrees with her husband's suggested solution, how can she enjoy having sex in such circumstances? If the husband forces his wife to do so then this constitutes marital rape, that is, sexual intimacy without her consent. The rationale would seem to be that sexual intercourse encourages the wife to reconcile. In rejecting the translation of sexual intercourse, I would offer a new way of interpreting the term daraba.

\footnotetext{
${ }^{63}$ Engineer, The Qur'an, Women, pp. 45-58; Wadud, Qur'an and Woman, p. 74-78.

${ }^{64}$ Daraba is as original form of wa idribū bunna. These terms may be used interchangeably.

${ }^{65}$ Nasaruddin Umar, "Kekerasan dan Kekuasaan," Jurnal Demokrasi dan HAM, vol. 2, no. 1 (May 2002), p. 59.

${ }^{66}$ Engineer, The Qur'an, Women, p. 54.

${ }^{67}$ Umar, "Kekerasan dan Kekuasaan."
} 


\section{Rereading of Qur'anic Text Using Hadith Approach}

The term daraba should be understood by 'making a decision', even though this translation has been realised neither in male Qur'anic commentators nor in feminist Muslim thinkers. I initiate such a translation for the following reasons.

Firstly, according to a famous Arabic dictionary, Lisän al 'Arab, the word daraba lexically has various meanings, including: (i) säfara (travel) e.g. idha darabtum fi al-ard / you travel in the world; (ii) nakaha (sexual intercourse) e.g. daraba al-fahl al-naqgah / the male camel has sexual intercourse with the female one; (iii) kaffa (split up) e.g. darabtu fulan 'an fulan / e.g. I split up two people who were in conflict; (iv) aqāma (decide) e.g. daraba al-rajul fi $\bar{i}$ al-bayt / someone makes a decision to stay home; (v) qada (makes a decision) e.g. fa daraba al-dabr darbanih/the decision has been made. It is also said that daraba is often used to mean $b \bar{a}^{-} a d a$ (disintegrate/separate) in the context of daraba al-dahr baynana/time has separated us. ${ }^{68}$ In line with these different usages of the term daraba, I prefer to translate it as qada (v) to indicate that a husband can make a decision to initiate divorce rather than legitimise physical punishment. The husband makes a decision in terms of exercising a choice to divorce if his wife still refuses to reconcile once intensive discussion and physical separation fail. At this stage, a private attempt between the two parties to resolve conflict is suggested in the Qur'anic verse (Q. 4: 34) rather than resorting to external mediation.

However, Qutb and Shihab argue that external intervention is needed at a different stage. Quṭ argues intervention from arbiters (mediators) at the first stage (verbal solution) is necessary when the parties private attempts to resolve conflict are unsuccessful. ${ }^{69}$ Others note that external intervention is required at the final stage. This means that external agencies, particularly from government bodies have the power to punish a non-compliant wife as the last resort, but it is not the husband's responsibility. ${ }^{70}$ However, it is difficult to accept advocates of the involvement from outsiders who argue it is sanctioned in the verse (Q. 4: 34) because the next verse (Q. 4: 35)

${ }^{68}$ Jamāl al-Dīn Muḥammad bin Mukrim bin Mandhūr, Lisān al-'Arab, Vol. I (Beirut: Dār al-Nashr, n.d.), pp. 543-551.

${ }^{69}$ Qutb, Fì Ziläl al-Qur'an, vol. 2, p. 653.

${ }^{70}$ Shihab, Tafsir al-Misbah, p. 411. 
offers alternative ways to resolve marital conflict, including seeking external intervention, particularly in the form of mediators for both parties. So, the direction to engage in intensive discussion, take separate beds, or for a husband to initiate divorce resided in the verse (Q. 4: 34). Only where these fail, should they seek external intervention from others such as family members, community elders, religious leaders or other related agencies as suggested in the verse (Q. 4: 35). If none of these efforts succeed, the husband can file for divorce by applying to the relevant institutions.

Secondly, it is important to challenge the translation of the term daraba as physical chastisement by considering the Prophetic traditions (ahääith) as follows:

"Do not strike your wife as if she were a slave, would you strike her and then at the end of the day you sleep with her". ${ }^{71}$

'A'ishah narrated that the Prophet Muhammad never struck a woman or a servant with his hand. He only raised his hand in jihād's for Allāh's cause. ${ }^{72}$

"The best among you (men) is if you treat your wife well (not struck them)". 73

Also, as described by 'Abduh, ${ }^{74}$ that praise a husband who can control his emotions and not use physical violence against women. There are different ways of understanding aḅa dith. Among these are local and global approaches. I emphasise that those aha adith contending appreciation for non-violent husbands should be understood in a global context because these are more relevant to current global views with respect to human rights including women's rights, and more

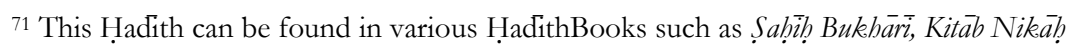
(93) and Kitāb Tafsìr al-Sürah (91); Saḅī Muslim, Kitäb Jinnah (49); Sunan Turmudhī, Tafsìr Sürah (91); Sunan Ibnu Mäjjah, Kitāb Nikạh (51); Sunan al-Därimī, Kitāb Nikēạ̣. (34); Musnad Aḥmad bin Hanbal, vol. IV, p. 17; Musannaf 'Abd al-Razzāq, vol. VII.

72 This Hadith was transmitted with various texts and can be found in: Sunan Abu Dāwūd, "Kitāb Adab" (4); Sunan Ibnu Mājjah, Kitab Nikah (51); Musnad Aḥmad bin Ḥanbal, Vol. VI, pp. 32, 206, 229, 232, 281; Sunan al-Dārimi, "Kitāb Nikāạ” (34).

73 Sunan Turmudhi, "Kitāb Raḍā" (11); Sunan Ibnu Mājjah, "Kitāb Nikāh" (50); Musnad Aḅmad bin Hanbal, Vol. II, p. 472.

${ }^{74}$ Informative explanations of these ahä $\bar{d} \bar{t} t h$ can be found in 'Abduh, Tafsìr al-Manār, vol. 5, pp. 75-76. 
importantly relevant to Islamic teachings, particularly those which advocate marriage based on love and respect. Thus, I prefer to adopt a contextual method in elaborating these ahadith, because this requires an interpretation of the verse (Q. 4: 34) which acknowledges gender equality.

However, a local approach should also be used to interpret those ahädith which emphasise physical chastisement against wife. These Prophetic traditions actually represent the historical cultural and social values of Arab society at a time when physical punishment was considered an appropriate form of discipline. The continuation of a wife beating ideology forms part of a patriarchal conspiracy perpetuated through religious interpretations. In this context, Engineer acknowledges that the Arab community was habituated to the use of physical punishment of wives, and this symbolised male domination. ${ }^{75}$ The historical Arabic cultural certainties, therefore, cannot be applied globally to other cultures, particularly to those against the use of violence to resolve conflict, such as in contemporary society in which community members as well as governments tirelessly campaign to free women from any form of violence.

The final reason for translating the term daraba as 'making a decision to initiate divorce' rather than using physical chastisement is guided by 'Abduh's proposal of another interpretation (ta'will) for the term wa idribū bunna. 'Abduh rejects an interpretation of wa idribū bunna as physical punishment commonly used in his era. According to 'Abduh, it is inconsistent with both the fundamental Islamic teachings of the purpose of marriage and those aḅa $\overline{d i t h}$ which privilege respectful and tolerant husbands. ${ }^{76}$ The idea of looking for another interpretation (ta'wil) offers a new paradigm for every Muslim scholar, regardless of their gender, to discuss the relevance of the Qur'anic text to the contemporary social context. As a female Muslim, I attempt to be directly involved in interpreting the Qur'an to empower women. This requires a continual process of self-critique, rather than being dependent morally and intellectually on male scholars or men in general as suggested by Barazangi. Muslim women, according to Barazangi, are not recognised as autonomous moral and rational beings as intended in the Qur'an. To be independent on these accounts,

75 Engineer, The Qur'an, Women, pp. 55-56.

76 'Abduh, Tafsìr al-Manār, vol. 5, p. 75. 
Muslim women should take part in interpreting the Qur'an as well as in decision-making because women also have the responsibility to act as trustees as men do. ${ }^{77}$

The Qur'anic concepts of men's guardianship or leadership of women and domestic violence rely on interpretative traditions. The progressive interpretation asserts that both men and women can be qawwamün or as protectors, maintainers or leaders if they have capacities and resources, including from inheritances or other financial resources and if they support their family using these resources. Existing interpretations that allow wife beating must be redefined from a gender perspective. Making a decision to initiate divorce instead of using violence is relevant to the essence of Islamic teachings, and to human rights concerns.

\section{Conclusion}

Admittedly, there are factors contributing to domestic violence in Indonesia. As reported from Makassar, the violence may result from trivial issue to challenge of women to men's authority. This violence does not cease even though state initiatives to prevent it in form of legal mechanism, such as Law 23/2004 on the Elimination of Domestic Violence, has been deployed. Widely-held interpretations to Islamic sources seem to maintain the violence although several contemporary scholars and women activists are arguing otherwise. For them, literal interpretation of the verse (Q. 4: 34) is no longer relevant to the contemporary society due to its contrary to Islamic teachings, particularly those which advocate marriage based on compassion and respect. As Prophetic traditions (aha $\bar{a} \overline{d i t}$ ) support and appreciate nonviolent husbands. It is, therefore, necessary to reread the term wa idribu bunna with 'making a decision' based on language, the verse connection (munasabah bayn al-ayah) and hadist considerations. If a wife continues to be 'nushiz' after the first and the second resolution fails, the husband is encouraged to make desicion wether he continues the marriage or telling his wife that marriage must be stopped. []

\section{Bibliography}

\section{Books and Articles}

Abdel Haleem. The Quran. Oxford: The University Press, 2005.

${ }^{77}$ Nimat Hafez Barazangi, Woman's Identity and the Qur'an, p. 115. 
'Abduh, Muhammad. Tafsìr al-Manār. Vol. V, Egypt: Al-Manār, 1328.

Al-Bukhari, Muhammad bin Ismā̄ìil. Sahịh Bukharīi. Singapora: Sulaiman Mar'i, n.d.

Al-Hibri, Aziza. "A Study of Islamic Herstory: Or How Did We Ever Get Into This Mess?”, Women's Studies International Forum, vol. 5, no. 2, 1982 .

Al-Qastalanī, Abī al-'Abbas Shihāb al-Dīn Ahmad bin Muhammad, Irshäd al-Shari: Sharb Șahịh Bukhäri. Vol. I; N.d.: Ṭab’ah wa alNashr wa al-Tawqifi.

Al-Qurțubi, Muḥammad bin Aḥmad. Al-jāmi' Li Aḅkam al-Qur'ān. Vol.5, n.d.

Al-Rāzi, Muhammad Fakhr. Tafsìr Fakhr al-Rā̌ri, Vol. 3, N.d: Dār alFikr.

Al-Zamakhsharìi, Abū al-Qāsim. Tafsìr al-Kashshäf, Vol. 1, Beirut: Dār al-Fikr, 1977

Anwar, Etin. Gender and Self in Islam. New York: Routledge, 2006

Al-Sijistāni, Abū Dāwūd Sulaymān bin al-Ash'ash bin Ishạaq, Sunan Abū Dāwūid. Vol. II; Bandung: Daḥ̄ān.

Barazangi, Nimat Hafez. Woman's Identity and the Qur'an: A New Reading. Gainsville: University Press of Florida, 2004.

Emerick, Yahija. The Complete Idiot's Guide to Understanding Islam, 2nd edn., Penguin Group, USA, 2004.

Engineer, Ali Asghar. The Qur'an, Women and Moderm Society, New Dawn Press Group, India, 2005.

Ibn Mandhūr, Jamāl al-Dīn Muhammad bin Mukrim. Lisān al-'Arab. Vol. I, Beirut: Dār al-Nashr, n.d.

Muslim, al-Imām Abū al-Ḥusayn Muslim bin al-Hajjāj al-Qushayrì al-

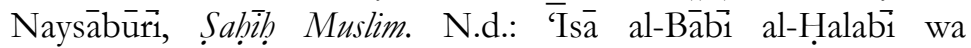
Sharakatuhu.

Quṭb, Sayyid. Fì Zilāl al-Qur'àn. Vol. 2, Egypt: Dār al-Shurūq, 1980

Shihab, M.Quraish. Tafsir al-Misbab: Pesan, Kesan dan Keserasian AlQur'an, vol. 2, Jakarta: Lentera Hati, 2002. 


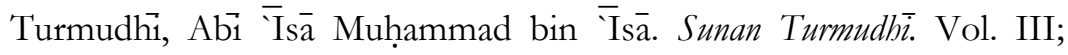
Beirut: Dar al-Fikr.

Umar, Nasaruddin. Argumen Kesetaraan Jender: Perspektif al-Qur'an. Jakarta: Paramadina, 1999

---------. 'Kekerasan dan Kekuasaan', Jurnal Demokrasi dan HAM, vol. 2, no. 1, May 2002

Wadud, Amina. Qur'an and Woman: Rereading the Sacred Text from a Woman's Perspective. New York: Oxford University Press, 1999 